\title{
CHARAKTER WŁASNOŚCI SIŁY ROBOCZEJ W GOSPODARCE REALNEGO SOCJALIZMU. DYLEMATY DOKTRYNALNO-POLITYCZNE I PRAKTYCZNE
}

\author{
Abstract \\ The character (feature) of labour force in real socialist economy. \\ Doctrinal, political and practical dilemnas
}

This article is an analysis of character of labour fource in real socialist economy. It attempts to answer the question, whether the system of labour fource in real socialist economy was based on the private property of labour force.

Słowa kluczowe: wolność pracy, niewolnictwo, komunizm wojenny, nowa polityka ekonomiczna (NEP) Keywords: freedom of work, serfdom, war communism, new economical politics (NEP)

ASJC: 3308, JEL: K31

\section{Wstęp}

O ile prawny (a w pewnym zakresie aksjologiczny) aspekt pracy i zakresu jej wolności można zrekonstruować na podstawie analizy obowiązujących norm prawnych, o tyle dopiero weryfikacja tych norm w praktyce gospodarowania zasobami ludzkimi może pozwolić na uchwycenie ekonomicznego aspektu tego zagadnienia. Sama wolność jurydyczna w oderwaniu od wolności ekonomicznej może bowiem odgrywać jedynie rolę martwej litery.

Wolność pracy w płaszczyźnie ekonomicznej występuje wówczas, gdy posiadacz siły roboczej jest jednocześnie jej prywatnym właścicielem i jako jednostka dysponująca wolnością osobistą ma prawo swobodnego użytkowania i rozporządzania swą siłą roboczą tudzież pobierania z tego pożytków. Oznacza to, że zawłaszczanie pracy może nastąpić jedynie za pośrednictwem kontraktu (wymiany pracy na 
płacę), a nie w drodze administracyjnego czy też wynikającego ze zwyczaju nakazu bądź polecenia ${ }^{1}$.

Mechanizmem gwarantującym w sensie ekonomicznym zawłaszczenie pracy na zasadzie wymiany kontraktowej może być jedynie rynek rozumiany jako struktura niehierarchiczna, oparta na prywatnej własności i zasadzie swobodnej wymiany (obrotu). Istnienie mechanizmu rynkowego jako sposobu alokacji zasobów pracy oznacza zatem, że:

1. pod względem prawnym podmioty występujące na rynku pracy są wobec siebie równorzędnie i dokonują dobrowolnych transakcji, kierując się interesem własnym;

2. pod względem ekonomicznym kanały przepływu zasobów pracy są poziome, a przenośność tych zasobów jest rezultatem oddolnych popytowo-podażowych sprzężeń na rynku pracy zdeterminowanych dostosowaniami popytowo-cenowymi w sferze zasobów rzeczowych ${ }^{2}$.

Aby mechanizm rynkowy mógł w praktyce zaistnieć jako sposób alokacji zasobów pracy, muszą być spełnione dwa warunki:

1. osoby zdolne do pracy są prywatnymi właścicielami swej siły roboczej, a własność ta jest wyłączna (ekskluzywna) i dobrowolnie transferowalna (przekazywalna) na okres trwania zatrudnienia ${ }^{3}$;

2. istnieją niezależni przedsiębiorcy potrzebujący do uruchomienia swego kapitału siły roboczej (Patulski 2019, s. 202).

Brak mechanizmu rynkowego jako sposobu alokacji zasobów pracy oznacza, że wolność pracy - nawet w sytuacji, gdy można ją zrekonstruować $\mathrm{z}$ analizy obowiązujących regulacji prawnych - jest ograniczona lub w ogóle zostaje przekreślona w płaszczyźnie ekonomicznej, a sama praca stoi w obliczu groźby uspołecznienia (czy etatyzacji), jeśli zjawisko to już wcześniej nie nastąpiło.

$\mathrm{Z}$ tego punktu widzenia powstaje problem charakteru siły roboczej w gospodarce realnego socjalizmu. Kategorię siły roboczej należy tu rozumieć jako zdolność wykonywania pracy, czyli odpowiednie cechy fizyczne, intelektualne i moralne umożliwiające jednostce wykonywanie pracy. Jest to kategoria obiektywna i uniwersalna, występująca w całej dotychczasowej historii ludzkości, we wszystkich znanych ustrojach społeczno-ekonomicznych. Innym zagadnieniem jest zaś gospodarka siłą roboczą, uwarunkowana konkretną, historycznie ukształtowaną formą ekonomiczną, występującą w danym sposobie produkcji. Kryterium odmienności formy ekonomicznej siły roboczej w każdym

1 Zawłaszczanie pracy w drodze decyzji administracyjnej na potrzeby społeczności lokalnej, choćby nastąpiło to wbrew woli zainteresowanego, jest dopuszczalne w pewnych sytuacjach przez normy prawa międzynarodowego, o czym bliżej w podpunkcie 3.3 (na przykład art. 2 ust.1 pkt e Konwencji nr 29 dotyczącej pracy przymusowej lub obowiązkowej, Dz.U. 1959, nr 20, poz. 122, przewidującej możliwość zarządzenia przez właściwe władze pracy przymusowej lub obowiązkowej w postaci „drobnych prac na rzecz społeczności lokalnej").

${ }^{2} \mathrm{~W}$ modelu doskonałego rynku pracy wahania płac (dostosowanie popytowo-cenowe) miały regulować podaż siły roboczej (dostosowanie ilościowe).

${ }^{3}$ W pracy na własny rachunek własność siły roboczej jednostki świadczącej pracę nie jest transferowalna, natomiast mogą być transferowalne produkty jej pracy. 
z historycznie znanych sposobów produkcji jest charakter własności siły roboczej rozumiany jako szansa podejmowania przez jednostkę efektywnych decyzji o sposobie użytkowania własnej siły roboczej. Co ważne, tylko jednostki mogą być traktowane jako dysponenci praw własności, co oznacza, że podejście w ramach teorii siły roboczej różni się od podejścia tradycyjnej nauki prawa (Alchian, Demsetz 1973, s. 17).

\section{Niewolnictwo a poddaństwo}

Z perspektywy historycznej należy odnieść się do dwóch zjawisk występujących w społeczeństwach przedkapitalistycznych, to jest niewolnictwa i poddaństwa. Zarówno niewolnicy, jak i poddani nie są właścicielami całości ani części swojej siły roboczej. Karol Marks pisał, iż „niewolnik wraz ze swą siłą roboczą jest raz na zawsze sprzedany swemu właścicielowi. On sam jest towarem, lecz jego siła robocza nie jest jego towarem” (Marks, Engels 1949, s. 78). Innymi słowy, niewolnik to taki bezpośredni producent, którego siła robocza stanowi obiekt cudzej własności (innego człowieka, grupy lub państwa $)^{4}$. Ekonomiczne zjawisko niewolnictwa jest zatem ściśle związane z kategorią prawną pracy przymusowej.

W okresie cesarstwa rzymskiego praca niewolników stawała się ekonomicznie coraz bardziej nieopłacalna i stopniowo zastępowano ją pracą kolonów, czyli poddanych chłopów. Zresztą w obrębie kategorii niewolników można było wyróżnić grupy, których status formalnoprawny różnił się od ich pozycji społeczno-ekonomicznej ${ }^{5}$.

System pracy niewolniczej skurczył się poważnie w okresie feudalizmu, dominując jedynie w koloniach. Jednocześnie wraz z kolonializmem umacniał się proceder handlu niewolnikami, który swe apogeum osiągnął w XVIII i na początku XIX wieku (w tym czasie wywieziono z Afryki od kilku do kilkunastu milionów Murzynów; Rusinowa 1983). W drugiej połowie XIX wieku, gdy mocarstwa kolonialne rozpoczęły intensywną eksploatację gospodarczą Afryki, do której była niezbędna miejscowa siła robocza, wywóz niewolników całkowicie zamarł.

System pracy niewolniczej powrócił w gospodarce przymusowej (Zwangswirtschaft) Trzeciej Rzeszy jako prawo własności państwa do niewolnika (Żydzi, cudzoziemscy

${ }^{4}$ Max Weber poddał analizie różne formy niewolnictwa w starożytnych Atenach (Weber 1967, s. 206 i n.; por. Kozyr-Kowalski 1988, s. 383).

${ }^{5}$ I tak w przeciwieństwie do servi vincti, czyli niewolników skutych, których używano do prac w winnicach, położenie społeczno-ekonomiczne niewolników servi casati zatrudnionych $\mathrm{w}$ wielkich gospodarstwach hodowlanych, których zajęcia wymagały pełnej swobody ruchów, było całkowicie odmienne. Panowie bowiem, chcąc zwiększyć ich wydajność, przekazywali im działki ziemi w użytkowanie jako peculium. Niewolnicy pracujący na peculium mogli mieć rodzinę, a pewna część plonów stanowiła ich własność. Choć w sensie formalnoprawnym byli oni nadal niewolnikami, to ich status społeczno-ekonomiczny przypominał bardziej sytuację kolonów, czyli poddanych chłopów w okresie cesarstwa rzymskiego (Jaczynowska 1984, s. 315-319). Ponadto lepsze niż niewolników pracujących na roli było położenie niewolników w mieście, tworzących familia Urbana, którzy mogli mieć nadzieję na wyzwolenie (Jaczynowska 1984, s. 117). 
przymusowi robotnicy, część jeńców wojennych, zwłaszcza radzieckich (Łuczak 1984, s. 243 ${ }^{6}$. Gigantyczny system pracy niewolniczej nie był ograniczony jedynie do terenów Rzeszy, ale występował przede wszystkim na ternach podbitych (Oświęcim, Majdanek, Sobibór itp.). Także doświadczenia krajów realnego socjalizmu w modelu polityki komunizmu wojennego (jego Stalinowska wersja), Kampuczy z lat 1975-1978, chińskiego wielkiego skoku naprzód (1958-1961) i rewolucji kulturalnej (1966-1970) wskazują na znaczące w tym czasie stosunki niewolnictwa (Patulski 1992, s. 191 i n.). Istnienie w gospodarce realnego socjalizmu systemu pracy niewolniczej związanej z obozami pracy lub komunami ludowymi rodziło pytanie, czy praca niewolnicza była nieuniknionym elementem socjalistycznych stosunków pracy, czy też jedynie rezultatem wypaczeń związanych z osobowością Stalina, Pol Pota czy Mao Ce-tunga. W literaturze przedmiotu przeważa podejście wiążące GUŁAG (czy komuny ludowe) z konstytutywnymi własnościami systemu w wersji komunizmu wojennego, w którym zanikły kategorie wartościowo-pieniężne, czyli odrzucono logikę rynku i pieniądza oraz nastąpiło utożsamienie władzy z własnością państwową (m.in. Mises 1981, s. 163 i n.). Teza o zanikaniu niewolniczego systemu pracy wydaje się zaś uzasadniona w odniesieniu do gospodarki realnego socjalizmu zmierzającej w kierunku NEP-u (czyli leninowskiej polityki odwilży i częściowej reaktywacji sektora prywatnego oraz tolerowania drugiej gospodarki, co zwiększało zakres indywidualnej swobody wyboru zawodu i miejsca pracy) ${ }^{7}$.

Poddaństwo z kolei było jedną z form prawno-ekonomicznej zależności drobnych rolników, związanej z podzieloną własnością ziemi. W klasycznej postaci poddaństwo wystąpiło w Europie w formie tak zwanego ustroju pańszczyźnianego, który obok ustroju czynszowego i najemnictwa tworzył ustrój feudalny (Rutkowski 1982, s. 111 i n.). W czystej formie ustroju pańszczyźnianego pańszczyzna robocza (renta odrobkowa) była jedynym ciężarem dworskim i polegała na wykonywaniu przez chłopów - w zamian za użytkowanie swych gospodarstw - różnego typu prac i posług na rzecz pana feudalnego, głównie przy uprawie pańskiego folwarku. Była to z reguły praca obowiązkowa i nawet jeśli nie występowała wraz z innymi formami renty (pieniężną, naturalną), można się było od niej zwolnić pod warunkiem wykupu za nieodrobione dni pańszczyzny (Rutkowski 1982, s. 125; Kozyr-Kowalski 1988, s. 381). W społeczeństwie feudalnym prywatna własność cudzej siły roboczej stanowiła zatem wspólną podstawę trzech głównych form poddaństwa: pańszczyzny, renty w naturze oraz renty pieniężnej. Poddaństwo oparte na pańszczyźnie, rencie w naturze czy rencie pieniężnej charakteryzowało się tym, że bezpośredni producent był częściowym właścicielem swej siły roboczej. Poddany mógł się stać wolnym pracownikiem najemnym, o czym świadczy ewolucja gospodarki towarowej w Europie, od przełomu XI i XII wieku rozluźniająca różne formy poddaństwa

${ }^{6}$ W rolnictwie Trzeciej Rzeszy pracowało około 2,5 mln zniewolonej siły roboczej rekrutującej się głównie spośród Słowian i Włochów (Kozyr-Kowalski 1988, s. 384).

7 Według radzieckiego planisty Włodzimierza A. Bazarowa w okresie NEP-u (1921-1927) około 80\% ludzi (chłopów, rzemieślników, chałupników, drobnych przedsiębiorców itp.) pracowało poza zasięgiem bezpośredniej kontroli państwowej (Zand 1983, s. 254). 
i zwiększająca zakres wolności osobistej bezpośrednich producentów, a w wyniku zwycięstwa rewolucji burżuazyjnych w Anglii i Holandii (XVI-XVII wiek), a następnie we Francji, oraz rozwoju stosunków towarowo-pieniężnych poddaństwo zaczęło zanikać. Poddany mógł stać się także „przypisanym do ziemi” (glebae adscripti), co nastąpiło w XVI wieku na wschód od Łaby, gdzie pańszczyzna została połączona z osobistym poddaństwem (określonym przez Engelsa jako „wtórne”). Chłopi „przypisani do ziemi” przestali dysponować wolnością osobistą, co przejawiało się w tym, iż nie wolno im było dobrowolnie opuścić gospodarstwa i mogli stać się - zwłaszcza w Rosji, gdzie poddaństwo przetrwało do lat sześćdziesiątych XIX wieku - przedmiotem handlu ${ }^{8}$.

Odpowiednikiem feudalnego poddaństwa związanego z pracą na roli była zależność występująca w ramach ustroju cechowo-korporacyjnego w miastach. Organizacja cechowa rzemieślników (mistrzów i czeladników) była uproszczonym sposobem planowania zatrudnienia (Olędzki 1978, s. 41-42) związanym z nierynkową regulacją dopływu zasobów pracy do rzemiosła. Sytuacja czeladników może być w płaszczyźnie społeczno-ekonomicznej i prawnej odniesiona do sytuacji chłopów przekazujących panu feudalnemu pracę dodatkową w postaci renty odrobkowej - z tym że ceną jest tu perspektywa samodzielnego wykonywania zawodu. Rozwój stosunków kapitalistycznych prowadził do likwidacji przywilejów stanowych, w tym przywilejów cechowych ${ }^{9}$ oraz pracy pańszczyźnianej jako mało wydajnej, i przestawienia się na wolny najem ${ }^{10}$.

Ujęcie siły roboczej jako obiektu własności pozwala skonstatować, iż różnica między pracą niewolnika a poddanego tkwi w stopniu zawłaszczenia ludzi. Niewolnik wraz ze swą całą siłą roboczą jest w sensie prawnym prywatną własnością innych w romanistycznym pojęciu własności jako ius utendi, fruendi et abutendi. Od statusu formalnoprawnego (czy zwyczajowego) należy odróżnić sytuację społeczno-ekonomiczną niewolników, która nie musi pokrywać się z ich pozycją prawną.

${ }^{8}$ W Polsce od XII wieku występowała również grupa chłopskiej ludności zależnej, głównie w dobrach kościelnych, niemającej prawa opuszczania ziemi i zwana „przypisańcami” (adscripti). Ponadto w wielu regionach Polski było rozpowszechnione zjawisko samowoli panów przy braku (lub kruchości) instytucji kontroli ze strony państwa. Różne formy poddaństwa ograniczały wolność osobistą poddanego, co nie znaczy, iż należy ją utożsamiać z „wolnością od robocizn”. I tak emfiteuci, okupnicy i czynszownicy w XVIII wieku w Polsce byli zwolnieni z pańszczyzny, renty w naturze czy renty pieniężnej, lecz wolność ta była ograniczona instytucją przymusowego najmu ich dzieci, co w praktyce przekreślało możliwość opuszczenia miejsca zamieszkania (Rutkowski 1986, s. 94-107).

9 Por. na przykład edykt wydany przez ministra finansów Ludwika XVI A.R.J. Turgota o zniesieniu cechów (Baszkiewicz 1983, s. 46 i n.). W początkowym okresie rozwoju manufakturowego także wykorzystywano na szeroką skalę pracę pańszczyźnianą, a nawet niewolniczą, czemu sprzyjał deficyt zasobów pracy. Siła robocza rekrutowała się zwykle spośród elementów spauperyzowanych, dzieci osieroconych, przestępców, żebraków i włóczęgów kierowanych administracyjnie przez władze państwowe do pracy w manufakturach (Olędzki 1978, s. 42).

${ }_{10}$ Przykładem jest tu przemysł śląski, który w ciągu ostatniego dwudziestolecia XVIII wieku przestawił się z pracy pańszczyźnianej na wolny najem (Gierowski 1989, s. 31). W świetle badań Witolda Kuli także manufaktury magnackie odchodziły stopniowo od pracy pańszczyźnianej, wprowadzając w nich bardziej wydajną i staranną pracę najemną. 
Natomiast chłop poddany zarówno w sensie formalnoprawnym (czy zwyczajowym), jak i społeczno-ekonomicznym nie jest właścicielem tej części swej siły roboczej, którą przekazuje panu feudalnemu w postaci pańszczyzny (renty odrobkowej), renty naturalnej lub renty pieniężnej. Zawłaszczenie części jego siły roboczej na rzecz pana feudalnego nie następuje dobrowolnie, co powoduje ograniczenie jego wolności osobistej i częściowe zawłaszczenie nim jako człowiekiem. Jego praca wykonywana w celu utrzymania siebie (i rodziny) stanowi zaś przedmiot jego osobistej (lecz nie prywatnej) własności. Prywatną własnością byłaby wówczas, gdyby mógł ją swobodnie zbywać na czas przez siebie określony, w drodze kontraktu innym osobom. Innymi słowy, prawa własności chłopów poddanych i zależnych do własnej siły roboczej nie mają charakteru prywatnego prawa własności - w romanistycznym ujęciu własności - i nie są ani ekskluzywne (wyłączne), ani dobrowolnie transferowalne. Stanowią one bowiem przedmiot własności łącznej (podzielnej) do zasobu, jakim jest siła robocza, to jest kompleksu praw przysługujących zarówno poddanym, jak i ich panom feudalnym. Własność łączna może ewoluować w kierunku przekształcenia w prywatną własność panów feudalnych (na przykład „przypisani do ziemi”) lub w prywatną własność posiadacza siły roboczej (pracownik wolnonajemny). W pierwszym przypadku poddani (zależni) stają się w sensie ekonomiczno-prawnym niewolnikami i mogą być, jako ludzie, przedmiotem handlu („martwe dusze” ze znanej powieści Gogola). W tym drugim przypadku stają się oni w sensie formalnoprawnym (zwyczajowym) prywatnymi właścicielami swej siły roboczej, co oznacza, że mogą ją zbywać w drodze kontraktu innym osobom na czas określony przez siebie. Formalnoprawna autonomia jednostki nie oznacza jeszcze, że w sensie ekonomicznym jest ona równorzędnym partnerem - nierzadko dopiero wczorajszego - byłego pana feudalnego, zwłaszcza jeśli zniesienie poddaństwa nastąpiło, tak jak w Rosji w 1862 roku, odgórnie ${ }^{11}$.

Elementy poddaństwa pojawiły się w XX wieku w gospodarce przymusowej Trzeciej Rzeszy $^{12}$ oraz w krajach realnego socjalizmu (Patulski 1992, s. 174-182) ${ }^{13}$.

${ }^{11}$ Problem własności siły roboczej w odniesieniu do społeczeństw przedkapitalistycznych pojawił się również w analizie tak zwanego azjatyckiego sposobu produkcji, wyróżnionego przez Karola Marksa. W związku z tym można spotkać się z terminem „niewolnictwo zbiorowe” wprowadzonym przez Lawrence’a Kradera na oznaczenie stanu zależności powstałego na tle wspólnej własności ziemi (Krader 1975, s. 289).

${ }_{12}$ Wprowadzono tam od 1938 roku zakaz zmiany zatrudnienia bez zgody urzędu pracy oraz obowiązek pracy. Uchylanie się od pracy było zagrożone skierowaniem do wychowawczego obozu pracy. Ilustracją reaktywowania instytucji pańszczyzny może być „służba pracy Rzeszy” (Reichsarbeitsdienst), którą objęto w latach 1935-1936 około 200 tys. młodzieży, a liczba ta w następnych latach ulegała sukcesywnemu zwiększeniu (Łuczak 1984, s. 163).

${ }_{13}$ Było to podyktowane także czynnikami politycznymi. I tak przykładowo w Czechosłowacji po interwencji wojsk Układu Warszawskiego w 1968 roku zwolniono około 150 tys. na 8 mln zatrudnionych i ograniczono im dostęp do pracy. Zwolnieni w tym trybie inteligenci zostali często zmuszeni do podjęcia pracy robotników drogowych, palaczy czy fryzjerów (Krawczyk 1990, s. 52). Podobnie było w Polsce z wieloma działaczami „Solidarności” po wprowadzeniu stanu wojennego w grudniu 1981 roku. 


\section{Spory na tle kwalifikacji siły roboczej jako kategorii ekonomicznej w marksistowskiej ekonomii politycznej}

W świetle doktryny marksistowskiej siła robocza w gospodarce socjalistycznej miała przekształcić się w jedną społeczną siłę roboczą obejmującą wszystkich indywidualnych wytwórców. Istnienie społecznej siły roboczej nie miało jednakże oznaczać odstąpienia od podziału części produktu społecznego przeznaczonego na reprodukcję siły roboczej. Kryterium tego podziału, na podstawie którego należało ustalić udział każdego wytwórcy w jego środkach spożycia, miał być czas pracy. Przewidywania klasyków marksizmu, iż w gospodarce socjalistycznej produkcja towarowa zaniknie, nie sprawdziły się. Dlatego też poglądy dotyczące formy ekonomicznej siły roboczej w gospodarce realnego socjalizmu są w marksistowskiej myśli ekonomicznej rozbieżne. Można tu wyróżnić trzy stanowiska:

1. Część ekonomistów reprezentuje pogląd, iż siła robocza podlega działaniu prawa wartości, a proces jej reprodukcji dokonuje się w warunkach stosunków towarowo-pieniężnych i istnienia najmu siły roboczej opartego na zasadzie ekwiwalentności. Gospodarka socjalistyczna w tym ujęciu różni się od kapitalistycznej brakiem wyzysku siły roboczej i racjonalnym jej gospodarowaniem wskutek planowego wykorzystania wymogów prawa wartości ${ }^{14}$.

2. W pracach niektórych ekonomistów radzieckich i polskich można spotkać się z poglądem o występowaniu w gospodarce socjalistycznej najmu siły roboczej przy jednoczesnym nietowarowym charakterze tej siły (Szafijew, Łokszin, Akopow 1960, s. 294; Morecka 1971, s. 899-917). W tym ujęciu siła robocza przestaje być towarem, gdyż społeczna własność środków produkcji likwiduje rozdzielenie producenta od tych środków. Jednocześnie siła robocza nadal pozostaje indywidualną własnością jej nosiciela, a jej przekazanie do dyspozycji społeczeństwa odbywa się w drodze najmu, który przybiera prawną postać umowy o pracę ${ }^{15}$. Ruch siły roboczej od jej indywidualnych posiadaczy do społeczeństwa odbywa się za pośrednictwem rynku pracy, a reprodukcja siły roboczej - przez konsumpcję środków kupowanych za dochody (płace) uzyskane w formie pieniężnej (Mujżel 1963, s. 140).

3. Część ekonomistów przyjęła tezę wydedukowaną z doktryny marksowskiej, iż w gospodarce socjalistycznej nie występuje najem siły roboczej, co oznacza, że nie jest ona towarem (Sabol ${ }^{16}$ 1960; Czuchno, Sajapin, Lichodiej 1968, s. 62; Melich 1971, s. 18-28;

14 Miftachow (1968, s. 12 i n.) stwierdził, iż „poprzez stosunki towarowo-pieniężne posiadające ekwiwalentny charakter dzięki pieniądzu (płace) i towarom (...) prawo wartości oddziałuje na proces reprodukcji siły roboczej, w ślad za czym występuje ona w gospodarce socjalistycznej jako kategoria wartościowa" (cyt. za: Obrębski 1977, s. 177).

15 Pojęcie prywatnej własności jest tu utożsamiane z pojęciem własności indywidualnej (osobistej), co wskazuje na brak dystynkcji między tymi całkowicie odrębnymi typami (tak przykładowo postępuje: Obrębski 1977, s. 178; Melich 1983, s. 47).

16 Ten autor nie jest jednak do końca konsekwentny, stwierdzając, iż „siła robocza w warunkach socjalizmu pozostaje prywatną własnością (...) każdy członek społeczeństwa socjalistycznego pozostaje prywatnym właścicielem swej siły roboczej” (s. 18 i 25 ). 
Obrębski 1977, s. 185). Zgodnie z tym ujęciem siła robocza przestaje być towarem, ponieważ pracownik jest współwłaścicielem środków produkcji i produktu społecznego. Udział pracownika w bezpośrednim podziale pracy społecznej oznacza, iż siła robocza nie podlega wymianie przez rynek pracy. Nie istnieje w związku z tym kategoria najmu siły roboczej, gdyż przekazywanie przez pracownika jego siły roboczej do dyspozycji społeczeństwa nie jest indywidualnym aktem, lecz zjawiskiem powszechnym odnoszącym się do całego zasobu ludności mającej zdolności wykonywania pracy. W konsekwencji pracownik nie może w procesie pracy dysponować swą siłą roboczą jak prywatny właściciel i musi podporządkować się decyzjom społecznym (Obrębski 1977, s. 181).

Przedstawione poglądy na charakter siły roboczej w gospodarce socjalistycznej nie są rezultatem analizy historycznej socjalistycznego sposobu produkcji, ale raczej intuicji bądź też dedukcji z góry przyjętych przesłanek normatywnych. Teza o nietowarowym, niewartościowym i nienajemnym charakterze siły roboczej wydaje się - z punktu widzenia analizy historycznej oscylowania państwa realnego socjalizmu między komunizmem wojennym a NEP-em w płaszczyźnie prawno-politycznej - najbardziej uzasadniona w odniesieniu do homogenicznego, socjalistycznego sposobu produkcji występującego w modelu polityki charakterystycznej dla komunizmu wojennego. Gospodarka w prawno-politycznym modelu komunizmu wojennego charakteryzuje się bowiem objęciem wszystkich (lub prawie wszystkich) obszarów gospodarowania socjalistycznym sposobem produkcji. Teza o nietowarowym charakterze siły roboczej oraz o występowaniu elementów najmu tej siły, którą reprezentuje przeważająca część ekonomistów marksistowskich, wydaje się zaś uzasadniona w odniesieniu do gospodarki zmierzającej w kierunku NEP-u, charakteryzującej się wycofywaniem państwa z socjalistycznego sposobu produkcji w pewnych obszarach gospodarowania (na przykład sektor prywatny, druga gospodarka). Nietowarowy charakter siły roboczej należy jednakże w tym ujęciu nadal odnosić do dominującego sektora socjalistycznego, w którego obrębie

występuje jeden pracodawca państwowy, a cena siły roboczej jest kształtowana w trybie administracyjnym (lub administracyjno-przetargowym). Z kolei teza o towarowym, wartościowym i najemnym charakterze siły roboczej nie znajduje empirycznego uzasadnienia w stosunku do żadnej z historycznie znanych odmian gospodarek realnego socjalizmu z przewagą socjalistycznego sposobu produkcji. Miałaby ona uzasadnienie dopiero w przypadku transformacji gospodarki realnego socjalizmu w gospodarkę rynkową, co oznaczałoby wprowadzenie autentycznego rynku pracy i rezygnację z centralnego planowania zatrudnienia (vide reforma Balcerowicza). Proces zjednoczenia Niemiec wymusił także we wschodnich Niemczech konieczność przeprowadzenia transformacji gospodarki w kierunku rynkowym. Słabością teoretycznych ujęć siły roboczej w obrębie marksistowskiej ekonomii politycznej jest „,kamuflowanie” pod pojęciem „towarowego charakteru siły roboczej" problematyki własności siły roboczej w gospodarce realnego socjalizmu. W tym sensie nastąpiło tu jakby pewne zerwanie ciągłości z marksistowskim ujęciem własności siły roboczej w formacji kapitalistycznej. Być może opory doktrynalne i cenzuralne sprawiły, iż marksistowska ekonomia polityczna nie poświęciła niewiele uwagi analizie różnych stadiów rozwojowych socjalistycznej formacji społeczeństwa 
przeprowadzonej z punktu widzenia ujęcia siły roboczej jako obiektu własności. Dlatego też wyłania się potrzeba spojrzenia na siłę roboczą z perspektywy teorii własności poprzez charakterystykę wiązek praw dotyczących użytkowania siły roboczej.

\section{Siła robocza na gruncie teorii własności}

W teorii własności siły roboczej zasadniczą kwestią jest odpowiedź napytanie, kto jest właścicielem siły roboczej jednostki: ona sama czy inni ludzie (lub instytucje). W literaturze marksistowskiej zajmującej się analizą formacji ekonomicznej społeczeństwa socjalistycznego najczęściej stosowaną kategorią teoretyczną było pojęcie własności środków produkcji. Kategoria własności siły roboczej pojawiała się z reguły przy okazji opisu społeczeństwa kapitalistycznego. Problematyka własności siły roboczej była rozpatrywana właściwie podczas dyskusji dotyczącej towarowego lub nietowarowego charakteru siły roboczej. Przyjęcie tezy o nietowarowym charakterze siły roboczej oznaczało - w kategoriach marksistowskiej ekonomii politycznej - negatywne rozstrzygnięcie kwestii prywatnej własności siły roboczej w socjalistycznym sposobie produkcji. Istnieją jednakże w literaturze marksistowskiej pewne próby interpretacji stosunków własności negujące społeczny charakter własności (czyli nietowarowości) siły roboczej w socjalistycznym sposobie produkcji. Wskazuje się tu na występowanie kategorii prywatnej własności siły roboczej rozumianej jako swoboda dysponowania obiektem własności, przejawiająca się prawem „samodzielnej decyzji co do podjęcia pracy w ogóle oraz wyboru zawodu i miejsca pracy" (Morecka 1964, s. 998). Pojęcie prywatnej własności siły roboczej było tu stosowane zamiennie z pojęciem własności indywidualnej (osobistej), co wskazuje na abstrahowanie od kryteriów rozróżnienia między społeczną, prywatną a osobistą własnością siły roboczej. Takie pomieszanie pojęć nie tylko sprzyjało chaosowi terminologicznemu, ale również prowadziło do zatarcia różnic między typami własności. Argumentem przeciwko koncepcji społecznej własności siły roboczej w gospodarce socjalistycznej był dla części autorów marksistowskich fakt „swobodnego wyboru pracy" ${ }^{17}$. W ten sposób dostrzeżenie przez niektórych ekonomistów marksistowskich pewnych przejawów wolności pracy w realnym socjalizmie pozwoliło im na przyjęcie istnienia kategorii prywatnej własności siły roboczej w ramach socjalistycznego sposobu produkcji.

Zwolennicy paradygmatu totalitarnego jako perspektywy teoretycznej analizy systemu socjalistycznego odwoływali się zaś często do pojęcia „niewolnictwa”, traktując je jako pojemną kategorię umożliwiającą opis i wyjaśnienie socjalistycznych stosunków pracy. Totalitarna interpretacja stosunków zatrudnienia w społeczeństwie socjalistycznym została zaprezentowana między innymi przez Hannah Arendt i Karla Augusta

17 Zdaniem autorów radzieckiego Wykładu ekonomii politycznej „określenie konkretnego miejsca każdego poszczególnego członka społeczeństwa w procesie pracy - jest w decydującej mierze sprawą danego członka społeczeństwa" (cyt. za: Tittenbrun 1982, s. 81). 
Wittfogela. Arendt w klasycznej już pracy Korzenie totalitaryzmu określiła ZSRR lat trzydziestych jako „gigantyczną organizację pracy niewolniczej” (Arendt 1966, s. 311). Wittfogel przeprowadził z kolei konfrontację wyników swych wieloletnich badań nad społeczeństwami „hydraulicznymi” ${ }^{18} \mathrm{z}$ marksizmem i polityczną praktyką państwa radzieckiego, określając w konkluzji społeczeństwo socjalistyczne jako „uprzemysłowiony system państwowego niewolnictwa” (Wittfogel 1958, s. 431 i n.).

Także marksiści odwoływali się często do kategorii „niewolnictwa”, aczkolwiek przy innej sposobności. Nawiązywali oni do wyodrębnionej w doktrynie marksistowsko-leninowskiej tak zwanej niewolniczej formacji społecznej powstałej na gruncie wspólnoty pierwotnej. W formacji tej niewolnictwo miało być dominującym sposobem produkcji. Problem formacji niewolniczej wywołał jednakże w intelektualnym środowisku marksistowskiej lewicy wiele kontrowersji. Jak wiadomo bowiem, Marks wyróżnił azjatycki, antyczny, feudalny i kapitalistyczny sposób produkcji. Stosunki niewolnictwa były w tym układzie dominujące w azjatyckim i antycznym sposobie produkcji (Marks 1972, s. 10). W okresie stalinowskim, poczynając już od lat trzydziestych, nastąpiło „odgórne" wyciszenie dyskusji na temat azjatyckiego sposobu produkcji i przyjęcie tak zwanej pięcioczłonowej koncepcji formacji społeczno-ekonomicznych: wspólnota pierwotna, niewolnictwo, feudalizm, kapitalizm i socjalizm (Minc 1987, s. 104). Ta koncepcja, odrzucająca azjatycki sposób produkcji, wychodziła z założenia, iż prawidłowości określające charakter sposobu produkcji są uniwersalne, a zatem na Wschodzie nie mógł się ukształtować sposób produkcji inny niż niewolnictwo i feudalizm (Minc 1987, s. 104). Bez względu na rozbieżności między marksowskim a przyjętym w literaturze marksistowsko-leninowskiej lat trzydziestych ujęciem formacji społeczno-ekonomicznych trudno jednak dowieść naukowo, że niewolnictwo dominowało w jakimkolwiek azjatyckim czy antycznym sposobie produkcji ${ }^{19}$.

Nasuwa się tu jednak pytanie, czy rzeczywiście teza, iż w gospodarce socjalistycznej dominowały stosunki niewolnictwa, prezentowana w różnych odmianach koncepcji totalitarnych, jest zasadna. Analiza historyczna oscylowania państw realnego socjalizmu pomiędzy komunizmem wojennym a NEP-em pozwala stwierdzić, iż jedynie w niektórych krajach i tylko w ramach realizacji modelu polityki komunizmu wojennego ujęcie stosunków pracy jako stosunków niewolnictwa może być uzasadnione. Wskazują na to przykładowo doświadczenia Kampuczy z lat 1975-1978, chińskiego wielkiego skoku

${ }_{18}$ Określenie to zastępuje wcześniej używane przez tego autora pojęcie społeczeństwa orientalnego, co miało zaakcentować cechy instytucjonalne, a nie geograficzne takiego społeczeństwa (Wittfogel 1956, s. 79).

19 Badania Williama L. Wastermanna (1955) wykazują, że w społeczeństwach antycznych praca niewolników nie odgrywała większej roli oraz że liczba niewolników była stosunkowo niewielka. Mając powyższe na uwadze, nie można abstrahować od zasadniczej różnicy między formalnoprawną a ekonomiczno-społeczną koncepcją siły roboczej. Niewolnik użytkujący w starożytnym Rzymie działkę ziemi (peculium) był w sensie formalnoprawnym nadal niewolnikiem, ale w sferze ekonomiczno-społecznej jego status był zbliżony do statusu kolonów. 
naprzód (1958-1961) i rewolucji kulturalnej (1966-1970)20. Większość społeczeństwa została w tamtych latach zamknięta w komunach podzielonych na brygady i zespoły, a instytucja gospodarstwa domowego uległa likwidacji. Cechą charakterystyczną niewolniczych stosunków społecznych w komunie była etatyzacja prywatnej egzystencji jednostek i całkowite dysponowanie ich siłą roboczą przez administrację partyjno-państwową, co w praktyce oznaczało, iż miejsce rynku pracy zajął terror rozumiany jako mechanizm mobilizacji i alokacji zasobów pracy, oparty na bezpośrednim stosowaniu przymusu fizycznego. Innymi słowy, większość nosicieli siły roboczej znalazła się w sytuacji, w której nie tylko ich zdolność do pracy, ale także oni sami jako ludzie stali się obiektem własności państwa (jego urzędników) w dosłownym romanistycznym ujęciu tej własności jako ius utendi, fruendi et abutendi. Jednostka nie mogła zatem podejmować żadnych efektywnych decyzji dotyczących sposobu użytkowania zarówno własnej siły roboczej, jak i własnej egzystencji. Na gruncie teorii własności siły roboczej sformułowanej przez szkołę praw własności można stwierdzić, iż wartość siły roboczej jednostki jest w takim przypadku równa (lub bliska) zeru, gdyż nie ma ona żadnych wyłącznych (ekskluzywnych) i przenoszalnych (transferowalnych) praw do swej siły roboczej. Następuje tu zatem zawłaszczenie ludzi wraz z ich siłą roboczą, a prawo własności państwa (jego urzędników) do jednostek można obrazowo określić za księciem de Blangis ze 120 dni Sodomy: „Dla świata jesteście martwi i nie będziecie traktowani jako ludzie, ale jak zwierzęta” (Ryszka 1985, s. 25). Koncepcje totalitarne operujące kategorią niewolniczych stosunków pracy nie są natomiast całkowicie przydatnym narzędziem badawczym w stosunku do doświadczeń realnego socjalizmu w wersji komunizmu wojennego, przez które przeszły ZSRR i inne europejskie kraje socjalistyczne. Dla najogólniejszej charakterystyki stosunków pracy występujących w tych krajach w ramach polityki komuizmu wojennego bliższe prawdy jest raczej stwierdzenie Maksa Webera, że mamy tu do czynienia z systemem opartym na powszechnej reglamentacji dóbr, dla którego pierwotnym wzorem może być starożytny Egipt z kombinowanym systemem pracy zawierającym elementy pracy wolnej (w tym pracy rodzin w ramach gospodarstw domowych), niewolnictwa i poddaństwa (Weber 1923, s. 282).

Ludwig von Mises przedstawił model biurokratyczno-koszarowej organizacji społeczeństwa socjalistycznego wydedukowany z doktryny marksistowsko-leninowskiej, zgodnie z którym wszystkie przedsiębiorstwa są agendami państwa, a każde pojedyncze gospodarstwo rolne, fabryka czy sklep są w takim samym stosunku do państwa jak urząd pocztowy do ministerstwa poczt. Siła robocza stanowi tu wielką armię pracy na przymusowej służbie (Mises 1981, s. 163). Biurokratyczno-koszarowy model społeczeństwa socjalistycznego, przedstawiony przez Misesa, może być traktowany jako uogólniony model rzeczywistości komunizmu wojennego w ZSRR w latach 1918-1921, gdy

20 Różnica między Chinami lat 1958-1961 i 1966-1970 a Albanią polegała między innymi na tym, że w chińskich komunach rolno-przemysłowych całkowicie znacjonalizowano życie osobiste jednostek, czego przejawem był na przykład wymóg zgody władz komuny na zawarcie związku małżeńskiego i przymusowa sterylizacja mężczyzn, których rodzina osiągnęła administracyjnie określoną liczbę osób. 
rządzący próbują przemocą - jak to ujął Nikołaj Bucharin - „za jednym zamachem zlikwidować stosunki rynkowe". Stosunki pracy w tamtym okresie łatwiej jest bowiem opisać i wyjaśnić w kategoriach hierarchicznych stosunków występujących w wojsku niźli niewolniczych stosunków pracy. Model Misesa jest jednakże moim zdaniem zupełnie nieprzydatny przy opisie polityki zmierzającej w kierunku NEP-u, gdy państwo wycofuje się z pewnych obszarów gospodarowania. Społeczeństwo, w którym występuje klasa średnia „nepmanów”, nie jest bowiem społeczeństwem homogenicznym, a istnienie sektora prywatnego i drugiej gospodarki zwiększa zakres indywidualnej swobody wyboru zawodu i miejsca pracy (Zand 1983, s. 254). Istnienie obszarów gospodarowania poza bezpośrednią kontrolą państwa umożliwia pojawienie się w miejsce przymusu jako czynnika produkcji nieobecnych dotąd interesów ekonomicznych. W tym momencie model Misesa, będący wynikiem logicznej dedukcji na podstawie z góry przyjętych przesłanek normatywnych, przestaje pasować do rzeczywistości realnego socjalizmu.

Istnienie w gospodarce realnego socjalizmu zmierzającej w kierunku komunizmu wojennego systemu pracy niewolniczej związanej z obozami pracy lub komunami ludowymi rodziło, jak wcześniej zaakcentowano, pytanie, czy praca niewolnicza była nieuniknionym elementem socjalistycznych stosunków pracy, czy też jedynie rezultatem wypaczeń związanych z osobowością Stalina, Pol Pota czy Mao Ce-tunga. Jak zaznaczono w podrozdziale 1 . „Niewolnictwo a poddaństwo" w literaturze przedmiotu przeważa podejście wiążące system obozów pracy (komun ludowych) z konstytutywnymi własnościami systemu, w którym zanikły kategorie wartościowo-pieniężne, czyli odrzucono logikę rynku i pieniądza, oraz nastąpiło utożsamienie władzy z własnością (tak zwana zasada jedności władzy i własności państwowej). Podkreślano także, że GUŁAG czy komuny były źródłem zaopatrzenia socjalistycznej gospodarki w tanią siłę roboczą, bez czego wielkie przedsięwzięcia gospodarcze byłyby skazane na niepowodzenie (Carrere dEncausse 1983, s. 13). Akcentowano też rolę etatystycznej tradycji Rosji przy okazji wyjaśniania genezy zsyłki czy katorgi (Sołżenicyn 2010, s. 324). W literaturze marksistowskiej dominowało zaś podejście wiążące niewolniczy sposób produkcji w okresie stalinowskim z socjalistyczną akumulacją pierwotną i polityką lat trzydziestych w ZSRR (Żukowska, Mejbaum 1980, s. 26-27). Rok 1954 stanowi w tym ujęciu umowną datę zakończenia okresu socjalistycznej akumulacji i likwidacji pracy niewolniczej w obozach pracy jako odrębnego sposobu produkcji (Żukowska, Mejbaum 1980, s. 26-27).

Takie podejście razi poważnymi uchybieniami. System obozów pracy istniał już w mniejszym zakresie w latach dwudziestych i istnieje nadal w czasach Putina (casus Chodorowskiego), a źródła tego stanu rzeczy są znacznie głębsze. Należy raczej wiązać je $\mathrm{z}$ istotą gospodarki realnego socjalizmu, która w wersji komunizmu wojennego pozostawia na scenie tylko jednego aktora - państwo. Żaden światowy system polityczny nie znał tak wielkiej koncentracji władzy ${ }^{21}$. Wobec braku rynku planista musi stosować

${ }^{21}$ Według Maksa Webera najbardziej przerażającą wizją jest społeczeństwo, w którym cały aparat państwowy byłby związany z bezpośrednim pracodawcą. W takim scenariuszu robotnik nie mógłby znaleźć nikogo, kto stanąłby po jego stronie (Weber 1958, s. 242 i 320). 
rachunek bezpośredni, a to oznacza w sferze zatrudnienia konieczność bezpośredniej alokacji pracy żywej, czyli przemieszczenie dużych zasobów pracy przez administracyjną (i ideologiczną) mobilizację. W przeciwnym bowiem razie bilans zatrudnienia mógłby się załamać (bo w jaki sposób - cytując Lenina - „zachęcić dobrowolnie do pracy katorżniczej?"). Jeśli do tego dodać, że plan w gospodarce socjalistycznej oscylującej w kierunku komunizmu wojennego miał charakter przede wszystkim polityczny, to jego niewykonanie groziło polityczną (a nawet karną) odpowiedzialnością. Zważywszy, iż rezerwy „emocjonalne” (subotniki, zaciąg komsomolski, przodownictwo pracy itp.) wyczerpują się z czasem, należy stwierdzić, iż brak mechanizmu rynkowego wymusza na władzy sięgnięcie po środki przymusu. Przymus staje się zatem jednym z czynników produkcji mającym substytuować niezbędne mechanizmy i interesy ekonomiczne oraz brak efektywności. Ten przymus w postaci postępującej etatyzacji siły roboczej i narzucenia administracyjnych ograniczeń, aby zapewnić priorytet przemysłowi państwowemu, stał się koniecznym elementem reprodukcji materialnej sektora państwowego (Staniszkis 1989 , s. 34). System pracy niewolniczej - jako jedna z postaci przymusu - był ponadto w okresie stalinizmu niezwykle efektywny politycznie w tym sensie, że izolował masy potencjalnych niezadowolonych. Obozy pracy i ich społeczny odbiór wpływały paraliżująco na jakąkolwiek próbę krytyki czy podjęcia antypaństwowej działalności. Zakładając, że polityczne czystki były koniecznością w procesie wymuszania jedności społecznej, obozy były tu także użytecznym produktem ze swoją piramidalną hierarchią odzwierciedlającą strukturę państwa - „lewiatana”. Należy jednak w związku z tym wyraźnie podkreślić, iż system pracy niewolniczej - w którego obrębie występowało, nawet w warunkach stalinowskiego terroru, zróżnicowanie ekonomiczno-społecznej sytuacji poszczególnych kategorii niewolników ${ }^{22}$ - nie wyczerpywał wszystkich form administrowania zasobami pracy (militaryzacja pracy, nakazy pracy, paszporty wewnętrzne, zakazy zmiany miejsca pracy itp.). Nie stanowił on także dominującego systemu pracy w okresie stalinowskim ${ }^{23}$. Przemoc nie musi zatem przyjmować w sposób nieunikniony

${ }_{22}$ Zróżnicowanie to było uwarunkowane między innymi poziomem kwalifikacji i umiejętności oraz stanem zdrowia świadczących pracę. Przykładowo więźniowie tak zwanych szaraszek, w których w ramach pracy przymusowej prowadzono prace naukowo-badawcze, jako osoby o najwyższych kwalifikacjach zawodowych i nieprzeciętnych umiejętnościach teoretyczno-praktycznych (na przykład konstruktorzy samolotów, radiowcy), mogli liczyć na znacznie lepsze warunki pracy i egzystencji niż więźniowie pracujący w kopalniach dalekiej północy czy przy wyrębie lasu w syberyjskiej tajdze. Więźniowie szaraszek - podobnie jak wykwalifikowani niewolnicy starożytnego Rzymu tworzący familia Urbana byli wprawdzie narażeni na kaprysy pana (władcy), ale mieli również możliwość zyskania ich łask, których zwieńczeniem mogło być wyzwolenie (zwolnienie z obozu). Tej nadziei był całkowicie pozbawiony niewolnik pracujący w kopalniach, kamieniołomach czy w tajdze. Sytuacja społeczno-ekonomiczna niewolników zależała więc $\mathrm{w}$ dużej mierze od wstępnej selekcji przy kierowaniu do określonych obozów. W wielu przejściowych obozach (na przykład Wanino) odbywały się swoiste targi niewolników: funkcjonariusze z poszczególnych obozów robili przegląd stanu fizycznego nowo przybyłych więźniów i wybierali najbardziej przydatnych (Kamiński 1990, s. 134; Roszkowski 1990, s. 16).

${ }^{23} \mathrm{~W}$ okresie największej eksploatacji niewolniczej siły roboczej, to jest w 1952 roku, w stalinowskich obozach pracy wykorzystywano - według danych radzieckich - pracę około $12 \mathrm{mln}$ ludzi. Nawet przyjęcie kryterium udziału pracy niewolniczej w produkcji nie pozwala na wyciągnięcie wniosku, iż 
formy pracy niewolniczej, nawet w odniesieniu do poszukiwania deficytowanych zasobów pracy w warunkach braku rynku. O użyciu tej właśnie formy przymusu w okresie stalinowskim zadecydowały, jak się wydaje, przede wszystkim następujące czynniki: budowa wielkich inwestycji i urzeczywistnianie innych przedsięwzięć w ramach przyspieszonej industrializacji w różnych, nieraz odległych częściach ZSRR (Ural, Kołyma, Kanał Białomorski itd.), brak kapitału, likwidacja sektora prywatnego, taniość i odnawialność niewolniczej siły roboczej² ${ }^{24}$.

System pracy niewolniczej mógł stanowić w tych warunkach najbardziej skuteczną oprócz „ochotniczego zaciągu” - metodę alokacji deficytowych zasobów pracy w logice ekstensywnej i nierynkowej gospodarki. Przemoc w postaci pracy przymusowej w obozach pracy nie była zatem „kaprysem” Stalina, ale jednym z możliwych warunków przyspieszonej industrializacji przy braku rynku i niskim poziomie technologicznym produkcji. Także doświadczenia innych krajów realnego socjalizmu wskazują, iż przemoc w dziedzinie zatrudnienia nie musi przybierać w sposób nieunikniony formy pracy niewolniczej. Owo - jak to określa Jadwiga Staniszkis - „drążenie w głąb systemu w poszukiwaniu właściwych dla niego metod mobilizacji zasobów" może przybrać formę militaryzacji produkcji, i to w podwójnym sensie: „narzucenia dyscypliny wojskowej i ograniczenia praw pracowniczych w newralgicznych działach produkcji oraz wykorzystywania poborowych jako siły roboczej" (Staniszkis 1989, s. 34). Nie ma zatem żadnych przesłanek pozwalających stwierdzić, iż praca niewolnicza jest na gruncie nierynkowym czymś nieuniknionym lub że odgrywa ona zawsze dominującą rolę w socjalistycznym sposobie produkcji. Analiza historyczna wykazuje, iż tylko w nielicznych krajach realnego socjalizmu i tylko w pewnych okresach system pracy niewolniczej był dominujący, a warunkiem tego była likwidacja instytucji gospodarstwa domowego. Natomiast $\mathrm{z}$ faktu, iż praca niewolnicza nie dominowała w większości krajów realnego socjalizmu, nie wynika jeszcze, iż nie występowała tam przemoc w dziedzinie zatrudnienia. Przemoc ta może bowiem przybierać różne formy (nakazy pracy, militaryzacja pracy, administracyjny zakaz zmiany miejsca pracy itp.), przekreślające rynkowy mechanizm alokacji zasobów pracy i oddziałujące na charakter własności siły roboczej. Celny wydaje się pogląd wyrażony przez Joan Robinson, iż „metody, które zapewniły sukces

społeczno-ekonomiczne stosunki niewolnictwa dominowały w okresie stalinowskim (Conquest 1971, s. $454-457)$.

${ }^{24}$ Przykładem może tu być wydobycie złota nad Kołymą, które ruszyło na większą skalę w 1927 roku. Początkowo prowadzili je wolni, indywidualni poszukiwacze, a państwo miało jedynie monopol skupu złota realizowany za pośrednictwem trustu Sojuzłoto. System państwowego monopolu skupu działał jednakże niedostatecznie sprawnie z punktu widzenia radzieckiego skarbu, co umożliwiało prywatnym poszukiwaczom omijanie przepisów i sprzedaż złota poza siecią państwową. Rząd, nie chcąc dopuścić do rozbudowy indywidualnego systemu wydobycia, a także nie posiadając kapitału, który umożliwiłby zorganizowanie przemysłowej eksploatacji państwowej, opracował na początku pierwszej pięciolatki system eksploatacji złóż kołymskich za pomocą pracy niewolniczej. Plan ten zbiegł się z początkiem kolektywizacji rolnictwa, której efektem były masowe deportacje „kułaków” i ich rodzin do łagrów. Deportacje te zatem połączono z programem rozwoju wydobycia złota na Kołymie (Roszkowski 1990, s. 8-9). Argument o taniości niewolniczej siły roboczej został zakwestionowany przez Andrzeja J. Kamińskiego (1990, s. 161). 
w uzyskaniu pełnego zatrudnienia i pełnego zużytkowania zasobów, stały się kajdanami na drodze dalszego rozwoju", gdyż zmuszają do stałego poszukiwania za wszelką cenę wolnych rezerw siły roboczej w miejsce wyczerpujących się zaangażowanych zasobów pracy (Robinson 1967, s. 37). Dlatego też nie można było w systemie realnego socjalizmu wykluczyć prawdopodobieństwa zastosowania na dużą skalę pracy niewolniczej lub innych form przemocy zmierzających do uspołecznienia siły roboczej.

Mając na uwadze dotychczasowe rozważania, można stwierdzić, iż na gruncie teorii własności ujawniają się uproszczenia teoretyczne związane z pojęciem niewolnictwa (sporne jest samo określenie tego pojęcia), które jakoby miało wyrażać w ramach paradygmatu totalitarnego typ ekonomiczno-społecznej własności siły roboczej dominującej w gospodarce socjalistycznej. Różne odmiany totalitarnych koncepcji operujących kategorią niewolnictwa w relacji do stosunków pracy w systemie realnego socjalizmu przybliżają najogólniejsze cechy socjalistycznej rzeczywistości okresu komunizmu wojennego, i to tylko w nielicznych krajach. Kategoria niewolnictwa użyta do opisu i wyjaśnienia funkcjonowania systemu realnego socjalizmu w tych odmianach, które oscylują w kierunku NEP-u, razi zaś swoją symplifikacją, uzasadniając zarzut publicyzowania czy wręcz nienaukowości. Odrzuca ona bowiem wszelki pluralizm, nie uwzględniając „szarych sfer” i dynamiki zmian zachodzących w społeczeństwach realnego socjalizmu.

Znacznie częściej i na większą skalę niż praca niewolnicza występowała bowiem w systemie realnego socjalizmu praca obowiązkowa, wykonywana na podstawie nakazów pracy, administracyjnego przedłużania okresów wypowiedzenia, zakazów zmian miejsca pracy (lub miejsca zamieszkania) czy zakazu pozostawania poza zatrudnieniem (tak zwany zakaz prowadzenia pasożytniczego trybu życia). Zawłaszczenie pracy następowało tu wbrew woli pracownika pod groźbą kary, prowadząc do ograniczenia zakresu jego osobistej wolności. Pracownik nie miał tu jednak statusu niewolnika w ekonomiczno-społecznym sensie, a bardziej zbliżał się do statusu poddanego, gdyż jego praca - podobnie jak to występowało w społeczeństwach "hydraulicznych” - była zawłaszczana przez państwo (w drodze administracyjnej lub karno-administracyjnej; Wittfogel 1958, s. 303). Można tu zatem mówić o skolektywizowaniu (zetatyzowaniu) własności części siły roboczej zawłaszczonej bezpośrednio (a nie w drodze wymiany) w celu zaspokojenia cudzych potrzeb na gruncie państwowej własności środków produkcji (etatystyczne poddaństwo; Tittenbrun 1982, s. 79-80). Zarówno w sensie formalnoprawnym, jak i ekonomiczno-społecznym podział własności siły roboczej między pracownika a państwo nie ma tu jednakże charakteru własności łącznej - jak w poddańczym systemie pracy opartym na rencie odrobkowej - gdyż opiera się on na państwowej własności środków produkcji, a nie na własności prywatnej. Pracownik nie może swobodnie zbyć praw do swej siły roboczej innemu podmiotowi w sytuacji monopolistycznej pozycji państwa jako pracodawcy. Przemoc występująca w formie pracy obowiązkowej nie pozostaje bez wpływu na charakter własności siły roboczej przez ograniczenie wyłącznych (ekskluzywnych) praw własności jednostki wobec swej siły roboczej do własności osobistej (indywidualnej) w ramach gospodarstwa domowego i likwidację (lub ograniczenie) przekazywalnych (transferowalnych) praw własności w stosunku do swojej siły roboczej na rzecz 
innego pracodawcy niż państwowego. Nie oznacza to, iż w płaszczyźnie ekonomicznej transferowalność tych praw nie może zostać rozszerzona, zwłaszcza w sytuacji istnienia drugiego obiegu. Drugi obieg, zwiększając transferowalność praw własności pracownika do własnej siły roboczej, rozszerzał tym samym zakres wolności pracy. W związku z tym należy zwrócić uwagę na zjawisko „fuchy” (chałtury), które charakteryzuje się - z punktu widzenia teorii własności siły roboczej - następującymi cechami:

- pracownik państwowy jako chałturnik występuje w płaszczyźnie ekonomicznej wobec kontrahenta jako prywatny właściciel swojej siły roboczej, działający na własny rachunek (może on zatem podjąć się wykonania zamówienia, ale może też odmówić);

- chałturnik w sensie formalnoprawnym jest pracownikiem, a więc właścicielem zależnym, który na podstawie stosunku pracy łączącego go z państwowym zakładem jest zobowiązany podporządkować się poleceniom kierownictwa tego zakładu dysponującego w procesie pracy prawami do jego siły roboczej;

- działanie na własny rachunek jest możliwe w sensie ekonomicznym dlatego, że chałturnik występuje wobec kontrahenta jako dysponent materiałów i narzędzi pracy stanowiących przedmiot własności państwowej i niedostępnych na ogół w sytuacji gospodarki niedoboru dla kontrahenta.

Te stwierdzenia prowadzą do przyjęcia następującego założenia wyjaśniającego: chałturnik jako prywatny właściciel swojej siły roboczej w sensie ekonomicznym może funkcjonować w tej roli jedynie pod warunkiem zatrudnienia w państwowym zakładzie pracy. Stosunek prywatnej własności do własnej siły roboczej w drugim obiegu może zatem w tym ujęciu powstać tylko na podstawie instytucji państwowego zakładu pracy i jest przez tę instytucję zapośredniczony (Mejbaum 1988, s. 39-40, 103). Chałturnictwo jako trwałe zjawisko ekonomiczno-społeczne jest możliwe na nietowarowym i nierynkowym fundamencie reprodukującym stały niedobór, co nie oznacza, iż nie występuje ono - tyle że w mniejszym stopniu - w gospodarce rynkowej ${ }^{25}$. Sytuacja ekonomiczno-społeczna chałturnika wykazuje pewne podobieństwo do sytuacji czeladnika w ustroju cechowo-korporacyjnym, którego przejście do samodzielnego wykonywania zawodu było hamowane. W swoistej „konkurencji” między chałturnikiem a prywatnym rzemieślnikiem w gospodarce socjalistycznej można się dopatrzyć także analogii historycznej przejawiającej się w walce cechów z „partaczami”, czyli spauperyzowanymi elementami ludności miejskiej niemającymi zezwoleń na prowadzenie działalności rzemieślniczej. Jednakże analogia ta jest w tym sensie zawodna, ponieważ „partacze” nie dysponowali właściwie cudzymi materiałami i narzędziami pracy. W systemie realnego socjalizmu niehomogeniczność stosunków własności siły roboczej przejawiała się także w kolektywnej wymianie siły roboczej, której zewnętrznym wyrazem było zjawisko nomenklatury. Władza stanowi tu kryterium społecznego „zamykania się” grupy dysponującej środkami przemocy i wytwarzania oraz posiadającej uprzywilejowaną pozycję w podziale

${ }^{25}$ Może ono występować także w systemie pracy niewolniczej, co ukazał Sołżenicyn w książce: Jeden dzień Iwana Denisowicza (1989). 
pracy $^{26}$. Symptomem kolektywnego charakteru monopolizacji określonych przywilejów jest stale obecna groźba „wypadnięcia” z nomenklatury, która może w sposób diametralny zmienić sytuację zawodową i materialną jednostki (talony, samochód, mieszkanie służbowe itp.) bez względu na posiadane przezeń kwalifikacje dotyczące pracy kierowniczej. W gospodarce realnego socjalizmu zmierzającej w kierunku NEP-u niektórzy przedstawiciele nomenklatury przystępują legalnie (lub półlegalnie) do sektora prywatnego, wykorzystując jako prywatny kapitał - prawo dysponowania deficytowymi środkami rzeczowymi. Mamy wówczas do czynienia ze swoistą reprywatyzacją własności państwowej (tak zwane uwłaszczenie nomenklatury) powstałą na fundamencie połączenia kolektywnej własności siły roboczej z prywatną własnością środków produkcji. Ta część nomenklatury zyskała tym samym sposobność, by stać się klasą w sensie Weberowskim, a więc o statusie materialnym regulowanym przez rynek (Staniszkis 1989, s. 88-89). Zjawisko „uwłaszczenia” nomenklatury wymaga kompleksowej analizy empirycznej i w tym miejscu jest jedynie sygnalizowane.

$\mathrm{W}$ gospodarce realnego socjalizmu - nawet $\mathrm{w}$ modelu polityki komunizmu wojennego - występuje praca wolnych ludzi w postaci osobistej własności siły roboczej, o ile zostaje zachowana instytucja gospodarstwa domowego. Członkowie gospodarstwa domowego są osobistymi (indywidualnymi) właścicielami swojej siły roboczej wykorzystywanej w celu zaspokojenia potrzeb rodzinnych. Podobnie właścicielami osobistymi swojej siły roboczej są użytkownicy ogródków warzywnych czy działek przyzagrodowych, których płody służą zaspokojeniu domowej konsumpcji.

W miarę wycofywania się z pewnych obszarów gospodarki państwo rezygnowało $\mathrm{w}$ coraz większym stopniu ze swych prerogatyw wynikających $\mathrm{z}$ imperium w stosunku do siły roboczej. Pojawienie się niepaństwowych pracodawców (rzemieślników, rolników, drobnych przedsiębiorców, firm zagranicznych itp.) rozszerza transferowalność praw jednostki do własnej siły roboczej uzależnionej dotychczas od monopolu państwowego pracodawcy. Konsekwencją tego jest poddanie sfery zatrudnienia w większym niż dotąd zakresie regulacjom zobowiązaniowym, opartym na kontrakcie, a nie na decyzji administracyjnej, a co za tym idzie - ewolucja od własności społecznej (etatystycznej) siły roboczej w kierunku prywatnej własności siły roboczej (pracownik wolnonajemny).

Opór pracowników (a zwłaszcza najsilniejszych grup robotniczych) wobec państwowego pracodawcy doprowadził w niektórych krajach realnego socjalizmu do ukształtowania się korporacyjno-przetargowego mechanizmu wymiany siły roboczej. Ten typ wymiany siły roboczej został zapoczątkowany w Polsce po 1970 roku wraz z zastosowaniem przez władze nowych technik absorpcji korporacyjnych form protestu robotniczego, które polegały na przetargach aparatu władzy ze strategicznymi grupami społecznymi i w języku urzędowym nosiły miano „konsultacji”. Tendencje te nasiliły się w ZSRR oraz w większości europejskich krajów realnego socjalizmu w latach osiemdziesiątych,

${ }^{26}$ Należy jednak pamiętać, że biurokracja w ZSRR po czystkach z lat 1936-1938 znalazła się w sytuacji niewiele różniącej się od innych grup pracowniczych - poza niewolniczą siłą roboczą (Weissberg-Cybulski 1967) i dopiero po XX Zjeździe KPZR w 1956 roku zapewniła sobie pełne bezpieczeństwo fizyczne. 
a spektakularnym ich przejawem były masowe strajki górników radzieckich latem i jesienią 1989 roku, zakończone zawarciem porozumień postrajkowych. Trudno natomiast ustalić empirycznie, w jakich formach i w jakim stopniu mechanizm ten rozwinął się $\mathrm{w}$ różnych krajach realnego socjalizmu.

\section{Podsumowanie}

Reasumując, można stwierdzić, że o ile w gospodarce kapitalistycznej dominuje homogeniczna własność siły roboczej w postaci prywatnej własności siły roboczej wraz z systemem pracy najemnej, o tyle w gospodarce realnego socjalizmu występowała niehomogeniczna struktura praw własności wraz z kombinowanym systemem pracy zawierającym elementy niewolnictwa, etatystycznego poddaństwa i pracy wolnych ludzi. Nie można dowieść naukowo, iż w gospodarce realnego socjalizmu występowała deterministyczna zależność między brakiem rynku pracy a systemem pracy niewolniczej. Nawet w warunkach Stalinowskiego terroru występowały różne typy własności siły roboczej, a praca niewolnicza nie odgrywała wówczas dominującej roli w socjalistycznym sposobie produkcji. Rozwój prywatnego i społecznego typu własności siły roboczej wraz z odchodzeniem od polityki komunizmu wojennego doprowadził do ewolucji państwowego monopolu pracy. Przykładem może być tu zjawisko instytucjonalizacji przetargu płacowego w latach siedemdziesiątych i osiemdziesiątych w niektórych europejskich krajach realnego socjalizmu czy „uwłaszczenia” nomenklatury. Wyższy stopień utowarowienia konsumpcji, wymuszając rozwój drugiego obiegu, zinstytucjonalizował zjawisko „fuchy” (chałtury), w którego ramach stosunek własności został zapośredniczony przez instytucję państwowego zakładu pracy. Konsekwencją , uwłaszczenia” nomenklatury czy chałturnictwa była swoista reprywatyzacja państwowej własności środków produkcji i pracy. Niemniej analiza historyczna wskazuje, iż ideologicznie skarlałe zdolność do pracy i wolność pracy w systemie realnego socjalizmu były kruche i permanentnie mierzyły się z realną groźbą uspołecznienia wraz z nawrotem polityki komunizmu wojennego. Wyjście z tej „pułapki hydraulicznej” - jeśli użyć określenia Wittfogela odnoszącego się do społeczeństw, ,hydraulicznych”, które znalazły się w swoistym stanie bezruchu, będącym dla ludzi, historii i kultury więzieniem na tysiąclecia (Wittfogel 1958, s. 420-421) - wymagało działań o charakterze antydoktrynalnym zmierzających do przekształcenia gospodarki realnego socjalizmu w gospodarkę rynkową, a więc do zupełnego wyjścia z logiki dotychczasowego systemu.

Mając powyższe na uwadze, można postawić następujące dwie tezy:

1. System pracy w gospodarce kapitalistycznej opiera się na prywatnej własności siły roboczej. Ponadto w gospodarce kapitalistycznej dominuje rynkowa alokacja zasobów pracy odwołująca się do ceny siły roboczej ${ }^{27}$.

27 Oczywiście mam na myśli ekonomiczny wymiar płacy, gdyż w płaszczyźnie aksjologiczno-prawnej akcentuje się, że „praca nie jest towarem” (stwierdzenia takie są zawarte w Konstytucji MOP i w deklaracji filadelfijskiej tej organizacji z 10 maja 1944 roku; Świątkowski 2008, s. 145, 148). 
2. System pracy w gospodarce realnego socjalizmu był natomiast oparty na niehomogenicznej strukturze praw własności i kombinowanym systemie pracy (z elementami niewolnictwa, poddaństwa i pracy ludzi wolnych $)^{28}$. Ponadto w gospodarce realnego socjalizmu dominowała nierynkowa alokacja zasobów pracy poparta przymusem pozaekonomicznym (Patulski 1992, s. 28).

\section{Bibliografia}

Alchian A., Demsetz H. (1973) The Property Rights Paradigm, „Journal of Economic History”, Vol. 33.

Arendt H. (1966) The Origin of Totalitarianism, New York.

Baszkiewicz J. (1983) Ludwik XVI, Wrocław.

Carrere dEncausse H. (1983) Stalin. Państwo terroru, tłum. J. Łęczycki, Warszawa.

Conquest R. (1971) The Great Terror: Stalin's Purge of the Thirthies, London.

Czuchno A., Sajapin J., Lichodiej B. (1968) Woznograżdienije za trud pri socjalizmie, Kijów.

Gierowski J.A. (1989) Historia Polski 1764-1864, Warszawa.

Jaczynowska M. (1984) Historia starożytnego Rzymu, Warszawa.

Kamiński A.J. (1990) Koszmar niewolnictwa, Warszawa.

Kozyr-Kowalski S. (1988) Struktura gospodarcza i formacja społeczeństwa, Warszawa.

Krader L. (1975) The Asiatic Mode of Production. Sources of Development and Critique in the Writings of Karl Marx, Assen.

Krawczyk A. (1990) Praska wiosna, „Więź”, nr 1.

Łuczak C. (1984) Dzieje gospodarcze Niemiec 1871-1945, Poznań.

Marks K. (1972) Przyczynek do krytyki ekonomii politycznej, tłum. E. Lipiński, Warszawa („Dzieła”, t. 13).

Marks K., Engels F. (1949) Dzieła wybrane, t. 1, Warszawa.

Mejbaum W. (1988) Własność jako przedmiot teoretyczny, „Colloquia Communia”, nr 4-5.

Melich A. (1971) Społeczna funkcja płac, Warszawa.

Melich A. (1983) Podstawy teorii płac w socjalizmie, Warszawa.

Miftachow H.M. (1968) Stoimost raboczej sity pri socjalizmie, Taszkient.

Minc B. (1987) Spór o istotne treści marksizmu, Warszawa.

Mises L. von (1981) Socialism: An Economic and Sociological Analysis, Liberty Classics, Indianapolis.

Morecka Z. (1964) Płaca ekonomiczna czy socjoekonomiczna [w:] A. Wakar (oprac.), Materiaty do studiowania ekonomii politycznej socjalizmu, Warszawa.

Morecka Z. (1971) System płac w gospodarce socjalistycznej, „Ekonomista”, nr 6.

Mujżel J. (1963) Stosunki towarowe w gospodarce socjalistycznej, Warszawa.

Obrębski T. (1977) Charakter sity roboczej w gospodarce socjalistycznej, „Ruch Prawniczy, Ekonomiczny, Socjologiczny", R. 39, z. 1.

${ }^{28}$ W systemie realnego socjalizmu można było „kupić” pracę, ale nie było możliwości wyceny jej ekonomicznej wartości (Staniszkis 1989, s. 30). 
Olędzki M. (1978) Polityka zatrudnienia, Warszawa.

Patulski A. (1992) Wolność pracy - próba ujęcia wielopłaszczyznowego, Warszawa.

Patulski A. (2019) Wolność pracy i zakaz pracy przymusowej [w:] K.W. Baran (red.), Zarys systemu prawa pracy, t. 9, Warszawa.

Robinson J. (1967) Collected Economic Papers 1951-1979, Vol. 4, Oxford.

Roszkowski W. (1990) Kołyma, „Przegląd Powszechny”, nr 1.

Rusinowa J. (1983) Tom czy Sam. Z dziejów Murzynów w Ameryce Północnej, Warszawa.

Rutkowski J. (1982) Wokół teorii ustroju feudalnego, Warszawa.

Rutkowski J. (1986) Wieś europejska późnego feudalizmu, Warszawa.

Ryszka F. (1985) Państwo stanu wyjątkowego, Wrocław-Warszawa.

Sabol W.A. (1960) Oczerki po woprosom balansa narodnego chozjajstwa, Moskwa.

Sołżenicyn A. (1989) Jeden dzień Iwana Denisowicza, tłum. W. Dąbrowski, I. Lewandowska, Warszawa.

Sołżenicyn A. (2010) Archipelag Gułag, tłum. M. Kaniowski, t. 3, Poznań.

Staniszkis J. (1989) Ontologia socjalizmu, Warszawa.

Szafijew K., Łokszin E., Akopow R. (red.) (1960) Politiczeskaja ekonomia socjalizma, Moskwa.

Świątkowski A.M. (2008) Międzynarodowe prawo pracy, t. 1: Międzynarodowe publiczne prawo pracy, Warszawa.

Tittenbrun J. (1982) Własność siły roboczej w socjalistycznym sposobie produkcji - społeczna czy prywatna?, „Ruch Prawniczy, Ekonomiczny, Socjologiczny”, R. 44, z. 1.

Wastermann W.L. (1955) The Slave System of Greek and Roman Antiquity, Filadelfia.

Weber M. (1923) Wirtschaftsgesichte, Tubingen.

Weber M. (1958) Gessamelere Politischne Schreifen, Tubingen.

Weber M. (1967) The Agrarian Sociology of Ancien Civilization, London.

Weissberg-Cybulski A. (1967) Wielka czystka, tłum. A. Ciołkosz, Paryż.

Wittfogel K.A. (1956) The Hydraulic Civilization [w:] Man's Role in Changing the Face of the Earth, Chicago.

Wittfogel K.A. (1958) Oriental Despotism, New Haven.

Zand H. (1983) Koncepcja budownictwa socjalizmu w myśli bolszewickiej, Warszawa.

Żukowska A., Mejbaum W. (1980) O Leszku Kołakowskim - literacie cywilizowanego świata, Warszawa.

\section{Akty prawa}

Konwencja nr 29 dotycząca pracy przymusowej lub obowiązkowej, przyjęta w Genewie dnia 28 czerwca 1930 roku, Dz.U. 1959, nr 20, poz. 122. 